\title{
IMMIGRANT SELECTION, HEALTH REQUIREMENTS, AND DISABILITY DISCRIMINATION
}

\author{
Douglas MacKay
}

\begin{abstract}
TIBERAL DEMOCRACIES often impose health requirements on prospective immigrants seeking permanent residency. First, many countries only admit 1 prospective immigrants who do not have a health condition that poses a significant risk to public health or public safety. Second, some countries also only admit prospective immigrants who do not have a health condition that is likely to result in "excessive" demands or burdens on publicly funded health and social service programs. Canada's Immigration and Refugee Protection Act includes both types of health requirements:
\end{abstract}

38(1) A foreign national is inadmissible on health grounds if their health condition

(a) is likely to be a danger to public health;

(b) is likely to be a danger to public safety; or

(c) might reasonably be expected to cause excessive demand on health or social services. ${ }^{1}$

While health requirements of the former type-i.e., $38(1)(a)$ and $38(1)(b)$-are prima facie reasonable, grounded in governments' duty to protect their citizens from harm, critics have rightly raised questions regarding the latter type of requirement, i.e., $38(1)(\mathrm{c})$. In practice, Canadian immigration officials enforcing $38(1)$ (c) have refused admission to prospective immigrants with disabilities, including people with Down syndrome, cerebral palsy, autism, paraplegia, and 
deafness. ${ }^{2}$ Critics have therefore argued that $38(1)(\mathrm{c})$, and policies similar to it, constitute a form of wrongful discrimination against persons with disabilities. ${ }^{3}$

In this paper, I investigate this charge. States arguably have a duty not to discriminate against prospective immigrants on the basis of race, religion, national origin, ethnicity, sex, gender identity, and sexual orientation, and, since disability is often considered to be a morally analogous feature of people's identity, it would seem to follow that states also have a duty not to discriminate against prospective immigrants on this basis. If this is true, health requirements such as $38(1)$ (c) — call them social cost health requirements — would be unjust.

In section 1, I provide a brief overview of social cost health requirements, using Canada's policy as a representative example, and suggest that these policies constitute a form of direct discrimination against prospective immigrants with disabilities. In section 2, I provide a freedom-based account of the wrongness of discrimination. According to this account, discrimination is wrong when and because it involves disadvantaging people in the exercise of their freedom on the basis of morally arbitrary features of their identity. Discrimination is permissible, I suggest, when it is necessary to advance a valuable exercise of the discriminating agent's freedom.

In section 3, I apply this account to the case of social cost health requirements. Against critics of these requirements, I argue that it is sometimes permissible for states to discriminate against prospective immigrants with disabilities. States may do so, I suggest, when such discriminatory treatment is necessary to significantly advance the realization of morally important purposes, for example, the promotion of citizens' health. Alongside critics of social cost health requirements, however, I argue that the existing policies of many states are a form of wrongful discrimination insofar as they are likely too broad to satisfy the above-mentioned standard. Focusing on Canada's policy in particular, I outline revisions that must be implemented if it is to be permissible.

In addressing the permissibility of social cost health requirements, I assume

2 McQuigge, “Ontario Family Denied Residency over Son's Down Syndrome”; White, "Physician's Family Fractured after Child with Cerebral Palsy Denied Entry to Canada”; McCulloch, "American University Professor in BC Denied Permanent Residence in Canada Due to Autistic Son"; Canadian Broadcasting Corporation, "Deported, Disabled uk Citizen Arrives in Britain"; Azpiri, "Case of Deaf Teenager Denied Immigration to Canada Discussed in House of Commons."

3 Waldeck and Guthrie, "Disability Discrimination and Immigration in Australia"; Hanes, "None Is Still Too Many"; Yu, "Ableism and Economic Rationalism in Australian Immigration"; Zaikowski, "Canada Is a Progressive Immigration Policy Dream; and Wilton, Hansen, and Hall, "Disabled People, Medical Inadmissibility, and the Differential Politics of Immigration.” 
that legitimate states possess a limited moral right to exclude prospective immigrants. ${ }^{4}$ After all, the question of the permissibility of these requirements only arises if states such as Canada possess such a right. This right is limited since it does not permit legitimate states to refuse entry to all prospective immigrants, for example, refugees who arrive at their borders. A consequence of this assumption is that, for at least some prospective immigrants, admission is a discretionary good - a good that legitimate states need not offer, and so to which no prospective immigrant has a claim right. ${ }^{5}$ As I explain below, this does not mean that states may distribute admission in any way they please.

\section{ARE SOCIAL COST HEALTH REQUIREMENTS DISCRIMINATORY?}

Social cost health requirements (scHRs) refuse permanent residency to prospective immigrants with health conditions that are likely to result in an "excessive" demand or burden on the receiving state's health and social service programs. Such requirements are employed by Australia, Canada, and New Zealand. ${ }^{6}$ Canada's SCHR offers a representative example: $38(1)(c)$ of Canada's Immigration and Refugee Protection Act directs immigration officials to refuse admission to prospective immigrants whose admission is likely to result in an "excessive demand" on health or social services. Until very recently, an excessive demand was defined as:

(a) a demand on health services or social services for which the anticipated costs would likely exceed average Canadian per capita health services and social services costs over a period of five consecutive years immediately following the most recent medical examination required under paragraph 16(2)(b) of the Act, unless there is evidence that significant costs are likely to be incurred beyond that period, in which case the period is no more than 10 consecutive years; or

(b) a demand on health services or social services that would add to existing waiting lists and would increase the rate of mortality and morbidity in Canada as a result of an inability to provide timely services to Canadian citizens or permanent residents. ${ }^{7}$

4 For what I take to be promising defenses of such a right, see Blake, "Immigration, Jurisdiction, and Exclusion"; and Miller, Strangers in Our Midst, 57-75.

5 Blake, "Immigration and Political Equality," 966.

6 Commonwealth of Australia, Migration Regulations 1994, Schedule 4; Immigration and Refugee Protection Act; Immigration New Zealand, Operational Manual.

7 Immigration and Refugee Protection Regulations, sOR/2002-227. 
In practice, under (a), Canadian immigration officials refused permanent residency to prospective immigrants with health conditions that were expected to result in fiscal costs that were greater than the per capita average-currently $\$ 6,655$ per year. ${ }^{8}$ Such conditions included Down syndrome, cerebral palsy, autism, paraplegia, and deafness. ${ }^{9}$ In response to a 2017 review of the policy by Parliament's Standing Committee on Citizenship and Immigration, the government department Immigration, Refugees and Citizenship Canada made two changes to the definition, taking effect on June $1,2018 .{ }^{10}$ First, the term "social services" is now understood to mean publicly funded social services that are closely related to health services rather than educational or rehabilitation services. ${ }^{11}$ Second, the cost threshold has been increased to three times the average Canadian per capita cost of health and social services. ${ }^{12}$

Importantly, not all prospective immigrants are subject to $38(1)(\mathrm{c})$. According to 38 (2) of Canada's Immigration and Refugee Protection Act:

38(2) Paragraph (1)(c) does not apply in the case of a foreign national who

(a) has been determined to be a member of the family class and to be the spouse, common-law partner or child of a sponsor within the meaning of the regulations;

(b) has applied for a permanent resident visa as a Convention refugee or a person in similar circumstances;

(c) is a protected person; or

(d) is, where prescribed by the regulations, the spouse, common-law partner, child or other family member of a foreign national referred to in any of paragraphs (a) to (c). ${ }^{13}$

Thus, $38(1)(c)$ applies to economic-class migrants and some family-class migrants, but not to humanitarian-class migrants, and not to family-class migrants who are spouses, common-law partners, or children of sponsors.

The number of prospective immigrants refused admission under $38(1)(c)$ has

8 Immigration, Refugees and Citizenship Canada, "Medical Requirements."

9 For a detailed overview of how $38(1)$ (c) is applied, see Standing Committee on Citizenship and Immigration, Building an Inclusive Canada.

Standing Committee on Citizenship and Immigration, Building an Inclusive Canada. Immigration, Refugees and Citizenship Canada, "Temporary Public Policy Regarding Excessive Demand on Health and Social Services." Immigration, Refugees and Citizenship Canada, "Temporary Public Policy Regarding Excessive Demand on Health and Social Services." 
been declining in recent years. In 2016, only 337 applicants were deemed inadmissible, compared to 473 in 2015 and 619 in $2014 .{ }^{14}$ To put these numbers in context, in 2015 Canada granted permanent residency to 271,847 people, including 170,398 in the economic category, 65,490 in the sponsored family category, and 32,115 in the resettled refugee and protected persons in Canada category. ${ }^{15}$ With the recent changes to the definition of "excessive demand," the number of prospective immigrants who will be refused admission to Canada under $38(1)(\mathrm{c})$ is expected to drop even further.

Are schrs such as Canada's discriminatory as their critics claim? Scholars offer conflicting accounts of the nature and types of discrimination. ${ }^{16}$ However, there is widespread agreement that discrimination involves treating members of a particular socially salient group-i.e., a group important to the structure of social interaction across a wide range of social contexts-worse than nonmembers because of their membership in that group. ${ }^{17}$ Clearly scHrs satisfy this definition.

First, these policies disadvantage certain prospective immigrants on the basis of their membership in a group, i.e., having a socially costly health condition. Second, most-if not all-members of this group are members of a group that is socially salient: persons with disabilities. Scholars disagree sharply on how to understand and define disability. ${ }^{18}$ However, there is consensus among a number of prominent official definitions of disability that disabilities have two common features:

1. A physical or mental characteristic that is, or is perceived as, an impairment.

2. Some personal or social limitation that is associated with that impairment. ${ }^{19}$

Harris, "'An Issue that Pulls at the Heartstrings.”

Government of Canada, "Facts \& Figures 2015.”

16

For different accounts, see Hellman, When Is Discrimination Wrong?; Lippert-Rasmussen, Born Free and Equal?; Khaitan, A Theory of Discrimination Law; and Altman, "Discrimination."

Hellman, When Is Discrimination Wrong? 13-15; Lippert-Rasmussen, Born Free and Equal? 45-46; Khaitan, $A$ Theory of Discrimination Law, 42-43; and Altman, "Discrimination."

For recent discussion of the different "models" of disability, see Shakespeare, Disability Rights and Wrongs Revisited, 9-91; Anastasiou and Kauffman, "The Social Model of Disability"; Beaudry, "Beyond (Models of) Disability?"; and Barnes, The Minority Body, 9-53.

19 Wasserman, Asch, Blustein, and Putnam, "Disability." The official definitions in question include those of the World Health Organization, the United Nations' "Standard Rules on the Equalization of Opportunities for People with Disabilities," the United Kingdom's Disability Discrimination Act, and the Americans with Disabilities Act. 
Many if not most socially costly health conditions are likely to count as disabilities on this definition. First, although the concept of health is contentious, on any reasonable conception most health conditions will be grounded in physical or mental characteristics that are impairments. As Jerome Bickenbach puts it, "whatever else it is, health is a state of a person's body, describable by the language of the biological sciences, broadly construed, and assessed against biostatistical norms of bodily functioning that, though fluid and changeable, are relatively stable over time and place." ${ }^{20}$ Furthermore, the question here is not whether socially costly health conditions are disabilities according to the true definition of health, but rather whether socially costly health conditions, as defined by SCHRs, satisfy the above definition of disability. ${ }^{21}$ Provided governments implementing SCHRs therefore understand health conditions in accordance with something like Bickenbach's characterization, most health conditions targeted by such policies will satisfy 1 .

Second, many if not most socially costly health conditions will also satisfy 2. While the majority of health conditions likely satisfy 2 , imposing limitations in the form of pain, reduced functioning, and/or a shorter life expectancy, socially costly health conditions will certainly do so since it is precisely these conditions that demand the attention of health and social services. If a health condition does not satisfy 2, why would governments devote resources to addressing it?

Given these two points, it is not surprising that wide-ranging health conditions are associated with disabilities including: (a) infectious diseases such as tuberculosis, HIV/AIDS, encephalitis, and meningitis; (b) noncommunicable chronic diseases such as diabetes, heart disease, mental disorders, cancer, and respiratory illness; and (c) injuries. ${ }^{22}$ It is also not surprising that the health conditions often targeted by scHRs are also disabilities, e.g., autism, Down syndrome, deafness, cerebral palsy, and paraplegia.

SCHRs therefore disadvantage prospective immigrants with socially costly health conditions, and most if not all of these health conditions constitute disabilities. SCHRs are therefore discriminatory policies, treating members of a

20 Bickenbach, “Disability, 'Being Unhealthy,' and Rights to Health,” 822.

21 Nor am I arguing here that all disabilities are best understood purely as health conditions. First, as the above-mentioned definition of disability indicates, some disabilities may be grounded in physical or mental characteristics that are simply perceived to be impairments, and so are unlikely to count as health conditions. Second, while many disabilities may be linked to a physical or mental impairment, they may not be best understood as "health conditions." Many of the personal and social limitations tied to a particular disability may be largely the result of the interaction of an impairment with the physical, built, and/or social environments. Bickenbach, "Rights to Health," 824-27.

World Health Organization, World Report on Disability, 32-34. 
socially salient group -i.e., disabled persons - worse than nonmembers-i.e., nondisabled persons - because of their group membership. Given the strong overlap between "socially costly health conditions" and disabilities, moreover, policymakers and immigration officials clearly know that SCHRs treat prospective immigrants with disabilities worse than prospective immigrants without disabilities. As such, the discrimination in question is a form of direct or intentional discrimination, a form of discrimination that is widely understood to face a higher justificatory burden than forms of indirect or unintentional discrimination. In the next section of this paper I investigate whether these policies are wrongfully discriminatory.

\section{WHEN IS DIRECT DISCRIMINATION WRONGFUL?}

Critics of schrs might think it obvious that these policies are unjust insofar as they constitute a form of direct discrimination. Much of the moral progress liberal democracies have made in the past few decades, after all, has been due to legal reforms prohibiting direct discrimination in employment, public accommodations, housing, and access to government services and benefits. However, this is a complicated issue. First, sCHRs involve governments discriminating against prospective immigrants, not citizens. ${ }^{23}$ One might argue that while it is unjust for governments to engage in direct discrimination domestically, it is not unjust for governments to do so internationally. Second, as I argue below, direct discrimination is permissible under certain conditions. Even if scHRs are discriminatory, to show that they are unjust, critics must establish the further claim that the kind of direct discrimination SCHRs practice is wrongful.

In this part of the paper, I provide an account of the wrongness of direct discrimination and specify the conditions under which it is morally permissible. Since SCHRs are a form of direct discrimination, I do not address the question of the wrongness of other forms of discrimination, e.g., indirect or structural. The basic idea of my account is that discrimination is wrong when and because it involves disadvantaging people in the exercise of their freedom because of features of their identity that are morally arbitrary. Governments ought not to disadvantage people in this way, I suggest, whether they are citizens or prospective immigrants, thus implying that governments have a duty not to wrongfully dis-

23 Here and below, for purposes of simplicity, I use the term citizen not only to include citizens, but also all noncitizen residents who possess similar robust claims of justice on government. This latter category includes legal permanent residents but may also include undocumented immigrants. For discussion of what states owe to undocumented immigrants, see Carens, The Ethics of Immigration, 129-47. 
criminate against both the former and the latter. My account falls into the family of liberty-or freedom-based accounts of the wrongness of discrimination. As will become clear below, my account is Rawlsian in spirit, making use of a number of Rawlsian concepts. However, it also borrows from the work of Sophia Moreau and Tarunabh Khaitan, prominent defenders of freedom-based views. ${ }^{24}$

My account of the wrongness of direct discrimination starts from the Rawlsian conception of persons as free and equal. Of central importance for our purposes here, people are free on this conception insofar as they possess the capacity to set, revise, and pursue a conception of the good life. ${ }^{25}$ People possess a highest-order interest in fully developing and exercising this capacity, and a higher-order interest in realizing their determinate plan of life. ${ }^{26}$ People are equal insofar as they possess equal moral worth: they are equally deserving of respect and it is equally important that they are able to exercise their freedom. ${ }^{27}$

Governments have a duty to respect people qua free and equal persons. In the exercise of their coercive power, for example through the enactment of legislation or the provision of benefits and services, governments must therefore recognize the equal importance of people's lives. This means that governments must ensure that, when they exercise their coercive power, they do not disadvantage people in the exercise of their freedom because of features of their identity that are morally arbitrary. Legislation that advantages or disadvantages people because of their race, sexual orientation, or religion, for example, is not consistent with a recognition that it is equally important that people possessing these different identities are able to exercise their freedom. ${ }^{28}$

It follows from this that governments have a duty to comply with a principle of equal protection or nondiscrimination. Such a principle requires governments, in the exercise of their power, not to disadvantage people on the basis of

24 See Moreau, "What Is Discrimination?"; and Khaitan, A Theory of Discrimination Law.

25 Rawls, "Kantian Constructivism in Moral Theory," 312-13.

26 Rawls, "Kantian Constructivism in Moral Theory," 312-13.

27 Rawls, "Kantian Constructivism in Moral Theory," 333. The accounts of Moreau and Khaitan start from a similar starting point. Moreau's account starts from the claim that people in a liberal society are entitled to a set of "deliberative freedoms"- that is, "freedoms to deliberate about and decide how to live in a way that is insulated from pressures stemming from extraneous traits of ours" ("What Is Discrimination?" 147). Khaitan's account starts from the premise that states have a duty to ensure that people have secure access to those goods they require if they are to be free to live a good life. Khaitan, A Theory of Discrimination Law, 122.

This idea is expressed in Rawls's design of the original position, which places features of people's identity that are morally arbitrary for the distribution of social primary goods behind the veil of ignorance. Rawls, A Theory of Justice, 17, 122. 
factors that are morally arbitrary. Examples of such principles include the Equal Protection Clause of the Fourteenth Amendment to the U.S. Constitution and the Equality Rights section of the Canadian Charter of Rights and Freedoms. ${ }^{29}$

Governments' duty to respect people qua free and equal persons also implies that they have a duty to design systems of private law in ways that ensure that people are not disadvantaged in the exercise of their freedom because of morally arbitrary features of their identity. By a system of private law here, I mean those legal rules that govern how private individuals and corporate agents may treat each other. A system of private law therefore includes laws governing employment, public accommodations, housing, and private associations. Since it is equally important that people can exercise their freedom, governments have a duty to ensure that systems of private law are not designed in such a way that permit people to be disadvantaged on the grounds of features of their identity that are morally arbitrary. Governments therefore have a duty to enact and enforce nondiscrimination laws in the contexts of employment, public accommodations, housing, and private associations. Examples of such laws include the Civil Rights Act of 1964, the Americans with Disabilities Act, and the Canadian Human Rights Act. These antidiscrimination laws ensure that people are not disadvantaged due to their membership in a socially salient group. ${ }^{30}$

Although antidiscrimination duties are most commonly understood to apply in the domestic context, I suggest that governments also wrong prospective immigrants when they enact immigration policies that disadvantage them on the basis of morally arbitrary features of their identity. Some scholars are skeptical of this claim, arguing that antidiscrimination duties apply in the domestic context in virtue of normatively relevant features that are present therein but absent elsewhere. Michael Blake puts the point this way:

There may be some basic principle of distributive fairness governing which discretionary immigrants shall be admitted; but I do not think any such principles will get us very far. The powerful egalitarian principles found in the domestic context are difficult to apply in the absence of such

U.S. Const. amend. XIV, $\$_{1}$; Canadian Charter of Rights and Freedoms.

Moreau understands the purpose of antidiscrimination laws that govern private interactions in a similar way. On her account, the purpose of antidiscrimination laws is to extend deliberative freedoms to all of us "by preventing our employers, service providers, landlords, and others from acting in ways that deny us opportunities because of [normatively extraneous] traits" ("What Is Discrimination?" 147). Khaitan's account of the basis of private actors' antidiscrimination duty is similar to my own. For Khaitan, states have a duty to ensure that citizens have access to those basic goods required to be free to live a good life and "can legitimately call upon non-state actors (within reason) to assist it in the performance of this duty" (A Theory of Discrimination Law, 195). 
a web of legal authority. Indeed, I think it plausible that many of the reasons we have for caring about distributive fairness simply do not apply in such a case. The most powerful arguments against discriminatory distributive principles make reference to the circumstances of shared citizenship; in the absence of such circumstances, it is hard to see what purchase arguments from distributive fairness might give us. ${ }^{31}$

I agree with Blake that the circumstances of shared citizenship provide a grounding role for a number of robust duties of distributive fairness, in particular duties of distributive justice. ${ }^{32}$ However, I fail to see why such circumstances are necessary for the applicability of an antidiscrimination duty. The chief premise of my account of the wrongness of discrimination is the claim that governments have a duty to respect people qua free and equal persons and so ought not to treat them differently on the basis of morally arbitrary features of their identity. Since prospective immigrants, like citizens, possess this moral status, it follows that governments ought not to wrongfully discriminate against both prospective immigrants and citizens. Prospective immigrants are free and equal persons, just like citizens, and so deserve to be treated as such.

This does not mean that governments have the same duties to foreigners that they have to citizens. Governments stand in a special relation to their citizens, coercively enforcing a legal system that governs important aspects of their lives, and so it is not implausible to think that governments have special duties to their citizens in virtue of this relation. ${ }^{33}$ However, prospective immigrants are moral equals, and so it is equally important that they be able to carry out those plans of life they take to be worth pursuing. Immigration policies that favor members of a particular race or religion constitute a failure to recognize the moral equality of prospective immigrants - that is, that it is equally important that people outside of these favored groups can exercise their freedom. In deciding whom to admit, governments may not therefore select or reject prospective immigrants on the basis of morally arbitrary factors. As David Miller puts it, "if John is going to be granted entry while Jaime is turned away, the latter must be offered relevant reasons for his unequal treatment"; to do otherwise is to "show disrespect," to treat him as though he "were of no moral significance." 34

Even if I am wrong that governments have a duty not to wrongfully discriminate against prospective immigrants simply in virtue of their status as free and

Blake, “Discretionary Immigration," 284. 
equal persons, other compelling arguments support this conclusion. First, Blake has argued elsewhere that governments exercise a form of coercive authority over prospective immigrants and so have a duty not to discriminate against them in virtue of this relationship. By applying for residency, Blake argues, prospective immigrants place "themselves within the coercive grasp of a foreign state for at least one act of adjudication." 35 Since coercion is "always prima facie an act in violation of moral equality," Blake argues, governments must exercise their coercive power over prospective immigrants in ways that are justifiable to them qua moral equals. ${ }^{36}$ Since prospective immigrants could not accept reasons that violate their moral equality, Blake concludes, governments may not implement policies that affirm the superiority of one category of person over another, i.e., wrongfully discriminatory policies. ${ }^{37}$

Second, Blake and Matthew Lindauer have argued in support of governments' duty to respect prospective immigrants as moral equals by appeal to governments' duties to their own citizens. By discriminating against prospective immigrants, Blake and Lindauer argue, governments do not wrong prospective immigrants, but they do wrong citizens who belong to the same socially salient group as the prospective immigrants in question..$^{38}$ On Blake's account, when governments implement a discriminatory immigration policy, they publicly announce that members of the socially salient group in question are morally inferior. Such an announcement wrongs citizen members of this socially salient group by disrespecting them qua moral equals, undermining their ability "to see themselves as full participants in the project of self-rule." 39

Lindauer makes a similar argument, suggesting that discriminatory immigration policies wrong citizens who identify with the prospective immigrants in question, that is, who are also members of the socially salient group in question and identify with the prospective immigrants in question on that basis. ${ }^{40}$ Where such relationships of identification hold between citizens and prospective immigrants, Lindauer argues, discriminatory treatment of prospective immigrants is

Blake, "Immigration and Political Equality," 968.

Blake, "Immigration and Political Equality," 968-69.

Blake, "Immigration and Political Equality," 971, 975. For a criticism of this argument, see MacKay, “Are Skill-Selective Immigration Policies Just?” For a promising response, see Blake, "Exclusion, Discretion, and Justice," 36-41. Across Borders."

Blake, “Discretionary Immigration," 284.

Lindauer, "Immigration Policy and Identification Across Borders," 286. 
disrespectful to citizens qua moral equals. ${ }^{41}$ For both Blake and Lindauer, therefore, because governments have a duty to respect their citizens as moral equals, they also have a duty to respect prospective immigrants as such by not implementing wrongfully discriminatory immigration policies. ${ }^{42}$

In their exercise of coercive power over their own citizens, in their treatment of prospective immigrants, and in their design of systems of private law, governments therefore have a duty to ensure that people are not subject to wrongful discrimination - that is, are not disadvantaged in the exercise of their freedom on the basis of morally arbitrary features of their identity. One might object that this conclusion has absurd implications. For example, if governments have a duty to design systems of private law in a way that ensures that people are not disadvantaged in the exercise of their freedom because of morally arbitrary features of their identity, it would seem to follow that it should be illegal for private associations such as churches or religious schools to favor members of their own faith when deciding whom to hire for clerical or educational positions. After all, surely religion counts as a morally arbitrary feature of people's identity.

This implication only follows, however, if we understand the concept of morally arbitrary features in a context-independent way. On this interpretation, certain features of people's identities are morally arbitrary in all contexts. Luck egalitarians, for example, might claim that these features are simply those that are unchosen. ${ }^{43}$ I understand the concept of morally arbitrary features in a context-dependent way. Whether a feature of someone's identity is morally arbitrary or not depends on the type of interaction in question and the nature of the agents who are party to the interaction. ${ }^{44}$ Thus, while religious faith is morally arbitrary in the context of a private for-profit employer deciding whom to hire, it is not morally arbitrary in the context of a private religious association deciding whom to hire for an educational or clerical position.

More specifically, I suggest that whether a feature is morally arbitrary or not

Lindauer, "Immigration Policy and Identification Across Borders," 286.

One problem with Blake's and Lindauer's arguments is that they cannot explain why it is wrong for governments to discriminate against prospective immigrants in cases in which there are no citizens who are members of the socially salient group that is the subject of the discriminatory policy. See Cole and Heath Wellman, Debating the Ethics of Immigration, 149. I agree that this is a limit of Blake and Lindauer's arguments, but given the diversity of most societies, their arguments still imply that most discriminatory immigration policies are unjust. In particular, because all societies have members with disabilities, their arguments still support the conclusion that governments have a duty not to discriminate against prospective immigrants with disabilities, which is the focus of this paper.

Scheffler, "What Is Egalitarianism?" 8-12.

4 See also Shiffrin, "Incentives, Motives, and Talents," 122-23. 
depends first on whether the feature in question is relevant to the treating agent given the purpose or purposes it aims to realize. A feature is relevant to the treating agent, I suggest, if differential treatment on the basis of that feature can reasonably be expected to significantly advance one or more of the treating agent's purposes, and if there is no nondifferential treatment that can be expected to do so that does not result in unreasonable burdens on the treating agent. Thus, religious faith is relevant to a Baptist church deciding whom to hire as a pastor since only the hiring of a faithful Baptist will allow the church community to significantly advance its aims of practicing its Baptist faith.

Whether a feature of someone's identity is morally arbitrary depends, second, on the relative value of the purpose the treating agent is aiming to realize. A feature is morally nonarbitrary, therefore, only if it is relevant to the treating agent's purpose, and the treating agent's purpose is more valuable than the purposes of those affected by the differential treatment that would be frustrated. With respect to individuals, the value of purposes, I suggest, is to be determined by appeal to the above-mentioned conception of citizens as free and equal persons concerned to realize their interests in setting and pursuing their plan of life. With respect to institutions and organizations-e.g., governments, private for-profit corporations, and private civic associations - the value of purposes depends on an understanding of the morally permissible raison d'être of the agent in question. ${ }^{45}$ The most important purposes of private citizens, therefore, include the exercise of their freedom - that is, the setting, revising, and pursuing of a plan of life, and the plans and projects most central to their conception of the good life. The most important purposes of institutions and organizations, by contrast, are those purposes most closely related to their morally permissible defining purpose.

Governments therefore have a duty, both in the exercise of their own coercive power, and in the design of systems of private law, to ensure that people are not disadvantaged because of features of their identity that are morally arbitrary given the context in question. A feature is morally arbitrary, on my view, when it is irrelevant to the significant advancement of the treating agent's relatively valuable purposes. This conclusion provides us with a basis for determining when direct discrimination is permissible, and when it is not.

Direct discrimination involves the disadvantageous treatment of members of socially salient groups. The features of people's identity that are typically referred to as morally arbitrary include those that are constitutive of socially salient groups: race, ethnicity, national origin, sex, gender identity, sexual orientation, disability, and religion. Because such features of people's identity are not

Khaitan, A Theory of Discrimination Law, 181. 
morally arbitrary in all contexts, it follows that it is sometimes permissible to treat people differently because of their membership in a socially salient group, i.e., to engage in direct discrimination. In these cases, those subject to discriminatory treatment are not disadvantaged because of a morally arbitrary feature of their identity because the feature in question is not morally arbitrary given the context. Given the above-mentioned account of when features are morally arbitrary and when they are not, I suggest that direct discrimination is permissible if:

1. the discriminatory treatment is expected to significantly advance the realization of one of the discriminating agent's purposes;

2. there is no less discriminatory means by which the discriminatory agent may significantly advance the realization of its purpose that would not result in undue burdens on it; and

3. the purpose of the discriminating agent is more valuable than the purposes frustrated by the discriminatory treatment.

Together, these three conditions express the idea that it is permissible for agents to disadvantage people on the basis of their membership in a socially salient group when this feature of their identity is not morally arbitrary given the context of interaction. The first specifies that the moral arbitrariness of such features is in part dependent on the purposes of the treating agent. Where discriminatory treatment significantly advances the purposes of the treating agent, the identity feature in question is a candidate for moral nonarbitrariness, i.e., it is potentially relevant, given the context of interaction. The second ensures that the feature in question is in fact relevant by specifying that there must be no reasonable nondiscriminatory means of realizing the purpose in question. The third ensures that, in the context of a liberal democratic society, the purpose of the discriminating agent is more valuable than the frustrated purposes of those subject to the discriminatory treatment.

The central motivating idea of this account is that the securing of people's ability to exercise their freedom through nondiscrimination legislation should not prevent or significantly burden the ability of private individuals and collective agents to realize relatively valuable purposes. In other words, my account recognizes that antidiscrimination requirements, which aim to facilitate people's abilities to participate in public life and carry out their projects and goals, may sometimes hinder or prevent other agents from realizing morally important purposes. ${ }^{46}$ My account aims to solve this conflict by requiring agents to treat people the same, thus enabling them to carry out their projects and life plans regardless of membership in a socially salient group, but not in cases in which

46 See also Moreau, “What Is Discrimination?” 163-69. 
such equal treatment threatens agents' ability to realize purposes that are more valuable than the purposes discriminatory treatment would frustrate. ${ }^{47}$ In other words, my account recognizes that discriminatory treatment may be necessary in some cases to allow treating agents to exercise their freedom to pursue their goals and projects. It offers a framework to adjudicate the conflicts that arise among agents concerned to set and pursue morally important purposes.

Let me turn to a number of cases to illustrate the implications of my account and demonstrate its plausibility. Consider employment discrimination first. My account implies that it is impermissible for employers to discriminate against employees on the basis of membership in a socially salient group except in cases where doing so satisfies 1-3. My account thus forbids the forms of employment discrimination that are prima facie objectionable, for example, discrimination on the basis of race, sex, gender identity, etc., that serve no morally important purpose. But, it also permits forms of employment discrimination that are prima facie reasonable. First, it permits religious institutions such as schools and churches to discriminate against prospective employees on the basis of religion for positions that involve either teaching or clerical duties. Such discrimination satisfies 1-2 since the favoring of members of the faith for clerical and educational positions is a necessary and effective means for realizing these institutions' purpose of practicing and promoting a particular religious faith. It also satisfies 3 since this purpose is a morally permissible, defining purpose of these institutions, and the purpose frustrated by the discriminatory treatment-i.e., the opportunity to work a particular job for a particular employer-is much weaker in comparison. As such, my account lends support to Title vil of the Civil Rights Act of 1964, which prohibits employers from discriminating against employees or prospective employees on the basis of race, color, religion, sex, or national origin, but exempts from this requirement any "religious corporation, association, educational institution, or society with respect to the employment of individuals of a particular religion to perform work connected with the carrying on by such corporation, association, educational institution, or society of its activities." ${ }^{48}$

My account also explains why it is sometimes permissible for employers to discriminate against persons with disabilities. Consider the case of a trucking company that refuses to employ a blind person as a truck driver. This refusal counts as a form of direct disability discrimination, but is permissible, on my account, since it satisfies $1-3$. The company's policy of only hiring sighted persons as drivers significantly advances the company's purpose of providing trucking services to clients, and the purpose in question is a defining purpose of the

Moreau, "What Is Discrimination?” 163-69.

Civil Rights Act of 1964, 42 U.S.C. \$2000(e). 
organization and so is more important than the purpose frustrated by the discriminatory treatment- the opportunity to work a particular job for a particular employer. My account is thus consistent with the Canadian Human Rights Act, which prohibits employers from discriminating against employees and potential employees on the basis of protected grounds, but also specifies that it is not discriminatory if "any refusal, exclusion, expulsion, suspension, limitation, specification or preference in relation to any employment is established by an employer to be based on a bona fide occupational requirement." ${ }^{49}$

Consider, next, governments' exercise of coercive power. As I note above, my account justifies the need for a constitutional nondiscrimination clause that prohibits governments from exercising their coercive power in a way that disadvantages people because of features of their identity that are morally arbitrary. As such, it supports the Equal Protection Clause of the Fourteenth Amendment to the U.S. Constitution, and the Equality Rights section of the Canadian Charter of Rights and Freedoms. Moreover, my account is largely consistent with the standards that both U.S. and Canadian courts employ to determine whether particular forms of discriminatory treatment are justifiable. For example, section 1 of the Canadian Charter of Rights and Freedoms permits the infringement of people's rights and freedoms - including those protected by the Equality Rights section - when such limits are "reasonable," "prescribed by law," and can be "demonstrably justified in a free and democratic society." ${ }^{50}$ To determine whether a law satisfies this standard, Canadian courts employ the Oakes test, which is similar to the account of permissible discrimination I present above. According to this test, the law must serve an objective that is "sufficiently important to warrant overriding a constitutionally protected right or freedom" and so "must relate to societal concerns which are pressing and substantial in a free and democratic society." ${ }^{51}$ In addition, the means of realizing this objective must be proportional to it—that is: (1) be "rationally connected" to the objective; (2) "impair the right in question as little as possible"; and (3) be proportional to the importance of the objective. ${ }^{52}$ Similarly, in the U.S., differential treatment of people by the government is constitutional provided it can pass a certain form of judicial review. ${ }^{53}$ For example, if the law in question treats people differently on the basis of race or national origin, it must pass the "strict scrutiny" test, a test similar to the account of permissible discrimination that I introduce above. As such, my account

49 Canadian Human Rights Act, R.S.C. 1985, c. H-6.

50 Canadian Charter of Rights and Freedoms.

51 R. v. Oakes, [1986] 1 S.C.R. 103.

52 R.v. Oakes.

53 U.S. Const. amend. XIV, $\$ 1$. 
can explain the permissibility of affirmative action college admissions policies at institutions receiving public funding, policies that the U.S. Supreme Court has judged to pass strict scrutiny. ${ }^{54}$ Although these policies favor applicants who are racial minorities and so seem to violate the Equal Protection Clause, the U.S. Supreme Court has decided that since universities and colleges have a compelling interest in securing the educational benefits of having a diverse student body, they may employ such admissions policies, provided these policies are narrowly tailored to achieving such goals. ${ }^{55}$

Finally, my account can explain the permissibility of forms of direct discrimination in contexts that tend not to be subject to antidiscrimination legislation. For example, it is prima facie permissible for private individuals to discriminate against prospective partners on a number of grounds. Suppose I sign up for an online dating service and have the option to list my preferences for the purposes of screening potential partners. If I am a straight woman, I might choose to only view the profiles of men. If I am a conservative Christian, I might choose to only see the profiles of other conservative Christians. In both cases, I directly discriminate against people because they are members of a socially salient group, i.e., I treat them worse because of their sex or gender identity in the former case, their religion in the latter. However, it does not seem as though I wrong anybody. My account explains why this is so. Private individuals should treat other people equally but may discriminate when doing so significantly advances the realization of relatively valuable plans and projects, e.g., achieving sexual satisfaction or complying with a particular religious faith. Insofar as certain features of prospective partners are relevant to the achievement of such purposes, and the discriminatory treatment in question only removes a person's opportunity to date a particular person, these features are not morally arbitrary for some people. ${ }^{56}$

54 Fisher v. University of Texas at Austin et al., 136 S.Ct 2198 (2016).

55 Fisher v. University of Texas at Austin et al.

56 Moreau and Khaitan defend similar accounts of the conditions under which discrimination is permissible and the limits of discrimination law. Moreau does not provide a "complete theory" of the limits of discrimination law but suggests that the need to limit antidiscrimination laws to certain social contexts and types of transactions can be explained by the need to protect the ability of treating agents to realize important values, including the values of autonomy and deep personal relationships ("What Is Discrimination?" 160-63). With respect to contexts and interactions that are subject to antidiscrimination law, Moreau suggests that discrimination can similarly be permissible when discriminatory treatment advances the ability of the treating agent to exercise its freedom in sufficiently important ways ("What Is Discrimination?" 163-69). More specifically, Moreau suggests that the freedoms of the discriminating agent must be balanced against the deliberative freedoms of claimants (“What Is Discrimination?” 163). Khaitan argues similarly that otherwise discriminatory action is justified when it is "proportionate," where an act is proportionate if "it seeks to 
Because individuals, unlike public institutions, have legitimate private purposes, they will therefore have a far more extensive sphere of action in which it is permissible for them to discriminate against others.

Governments therefore have a duty to treat both citizens and prospective immigrants as free and equal persons. However, this does not imply that direct discrimination is always wrong. What are the implications of this account for the permissibility of scHRs?

\section{SCHRS AND PERMISSIBLE DISCRIMINATION}

SCHRs directly discriminate against prospective immigrants with disabilities. Contra critics of these policies, this does not necessarily imply that SCHRs are unjust. However, for this discrimination to be morally permissible, scHRs must satisfy the above three conditions of permissible direct discrimination. To determine whether some form of SCHR can satisfy this account, I focus on Canada's SCHR. As I note above, Canada's SCHR is similarly structured to those of Australia and New Zealand and so the lessons we draw below also apply to these policies.

Recall that, according to my account, direct discrimination is permissible if:

1. The discriminatory treatment is expected to significantly advance the realization of one of the discriminating agent's purposes;

2. there is no less discriminatory means by which the discriminatory agent may significantly advance the realization of its purpose that would not result in undue burdens on it; and

3. the purpose of the discriminating agent is more valuable than the purposes frustrated by the discriminatory treatment.

To determine whether Canada's SCHR satisfies these conditions, it is helpful to first identify its purpose. Recall from above that Canada's SCHR aims to prevent the imposition of an "excessive demand" on Canada's health and social services where an "excessive demand," according to the recently updated definition, is:

(a) a demand on health services or health-related social services for which the anticipated costs would likely exceed three times the average Canadian per capita health services and health-related social services costs over a period of five consecutive years immediately following the most recent medical examination required under paragraph

achieve a legitimate (and, sometimes, sufficiently important) objective, is suitable and necessary for achieving that objective, and is proportionate in the narrow sense (i.e., the benefit that is likely to accrue is not outweighed by the harm done by the discriminatory act" ( $A$ Theory of Discrimination Law, 181). 
16(2)(b) of the Act, unless there is evidence that significant costs are likely to be incurred beyond that period, in which case the period is no more than 10 consecutive years; or

(b) a demand on health services or health-related social services that would add to existing waiting lists and would increase the rate of mortality and morbidity in Canada as a result of an inability to provide timely services to Canadian citizens or permanent residents. ${ }^{57}$

The purpose of Canada's SCHR is thus to prevent the imposition of two types of costs on citizens. The first type, specified in (a), is a financial cost to taxpayers. As such, one goal or purpose of Canada's SCHR is simply to save taxpayers money. The second type of cost Canada's SCHR aims to prevent is an increase in morbidity and/or mortality rates for citizens, specified in (b). The concern here is that the admission of prospective immigrants with particular types of health conditions may decrease citizens' access to urgent and scarce health and social service programs, e.g., life-saving programs for which there are waiting lists. Given that Canada's SCHR aims to prevent the imposition of these two types of distinct costs, it aims to achieve two distinct purposes: minimize financial costs to taxpayers and promote citizens' health.

Are either of these goals morally important purposes for liberal democracies? Recall from above that, for collective agents, morally important purposes are those related to their raison d'être. The raison d'être of liberal states is widely understood to include the securing of citizens' basic rights and liberties and the just facilitation of their ability to set and pursue their chosen plans of life. More specifically, taking Rawls's conception of the person as a premise, the raison d'être of liberal states involves the just fulfillment of citizens' highest-order interest in fully developing and exercising their capacity for a conception of the good life, and their higher-order interest in realizing their determinate plan of life. ${ }^{58}$ Justly fulfilling the former, according to Rawls, requires securing citizens' basic rights and liberties, ensuring their basic needs are met, and ensuring they have access to health care. ${ }^{59}$ These goods, Rawls claims, provide people with the material basis for life and a protected sphere of personal sovereignty, both preconditions of the full development and exercise of their capacity to set and pursue a plan of

Canada is of course a federation, with federal and provincial governments sharing funding responsibilities for a number of health and social service programs. For purposes of simplicity however, here and below, I simply refer to Canada or the Canadian government as bearing these responsibilities.

58 Rawls, "Kantian Constructivism in Moral Theory," 312-13.

59 Rawls, Political Liberalism, 7, 308, and Justice as Fairness, 171-73. 
life. ${ }^{60}$ Justly fulfilling people's higher-order interest in realizing their determinate plan of life, Rawls claims, involves putting the social and educational programs in place that are necessary to provide fair opportunities to all regardless of socioeconomic class, justly distributing income and wealth, and facilitating economic efficiency. ${ }^{61}$ The fair provision of opportunities and income and wealth, Rawls claims, facilitates people's pursuit of "a wide range of ends, whatever they happen to be." ${ }^{2}$

On this understanding of the raison d'être of liberal states, promoting citizens' health is clearly a morally important purpose. People must be healthy if they are to realize their highest-order interest in fully exercising their capacity to set, revise, and pursue a plan of life. ${ }^{63}$ It is less clear, however, that minimizing financial costs to taxpayers satisfies this criterion. Although liberal states clearly have an interest in minimizing costs to taxpayers, I would suggest that this interest is best understood not as a goal or purpose of liberal democracies, but rather as an important consideration in their choice of means to achieve their goals or purposes. The imperative to minimize costs is thus an implication of the principle of instrumental rationality insofar as minimizing costs allows governments to realize their goals or purposes to a greater degree than they otherwise could.

This is not to say that minimizing costs to taxpayers is unimportant to liberal democracies or unrelated to their morally important purposes. By minimizing costs, after all, governments have more resources to better fulfill their morally important purposes. I suggest therefore that the concern of Canada's SCHR to minimize costs to taxpayers should be framed differently. That is, targeting health conditions that result in greater than average fiscal costs on health and social services can be understood as a way in which Canada can ensure that it has the financial resources to fulfill its morally important purposes, whether these involve promoting citizens' health, satisfying citizens' basic needs, facilitating economic growth, or providing the social and educational programs necessary to secure fair equality of opportunity for all citizens. ${ }^{64}$

Canada's SCHR can therefore be understood as a means to realize Canada's morally important purposes, including that of promoting citizens' health. To satisfy (1) however, it must significantly advance the realization of these purposes. Can Canada's schr, as currently designed, be expected to do so?

Determining what counts as a significant promotion of Canada's morally im-

60 Rawls, Political Liberalism, 7, 308, and Justice as Fairness, 171-74.

61 Rawls, Political Liberalism, 6, 308.

62 Rawls, Political Liberalism, 308.

63 See MacKay, "Calculating QALYs."

64 See also Khaitan, A Theory of Discrimination Law, 187. 
portant purposes and whether Canada's SCHR accomplishes this requires careful empirical and normative judgment. Until Immigration, Refugees and Citizenship Canada's recent change to the definition of an "excessive demand," an excessive demand included the imposition of costs on health and social services that were simply likely to exceed the per capita average. On this formulation, a prospective immigrant with a disability would be inadmissible if it were likely that her admission would result in slightly higher than average costs on health or social services. It is reasonable to think that this definition of an excessive demand would not satisfy (1) and so that Immigration, Refugees and Citizenship Canada was correct to revise it. First, the admission of prospective immigrants who met this interpretation of excessive demand need not have any significant effect on Canada's ability to fulfill its morally important purposes. For example, suppose that, on average, the prospective immigrants with health conditions who satisfy this criterion are likely to make use of $\$ 8,000$ per year of health and social services-compared to the per capita average of $\$ 6,655$ per year. Given that the prospective immigrants refused entry to Canada under 38 (1)(c) typically number in the hundreds, it is possible that admitting them will have no significant effect on the financial resources of the Canadian government. Second, since the concern is that prospective immigrants with disabilities will cause fiscal costs on Canada's health and social service programs, consideration must be given to the fiscal contributions of either the disabled prospective immigrant or those members of her family who will accompany her. Given that most prospective immigrants subject to $38(1)$ (c) are economic class migrants, there will no doubt be cases where the extra cost borne by Canadian taxpayers is outweighed by the fiscal contributions of her or her family members.

Would Immigration, Refugees and Citizenship Canada's updated definition of "excessive demand" satisfy (1)? Recall that, on this definition, costs are excessive only if they are likely to be at least three times the average per capita cost. It is difficult to tell whether the admission of prospective immigrants with disabilities who meet this definition would significantly impact Canada's realization of its morally important purposes since Immigration, Refugees and Citizenship Canada has not been forthcoming on the considerations it used to decide on this number. Although I am not therefore in a position to specify whether this revised definition satisfies 1 or not, it is possible to provide a normative standard by which this question can be decided. I suggest that $38(1)$ (c) would satisfy 1 if "excessive demand" is interpreted as:

(a) a demand on health services or social services for which the anticipated net costs, considered individually or in the aggregate, are great 
enough to significantly impact Canada's ability to realize one or more of its morally important purposes; or

(b) a demand on health services or social services that would add to existing waiting lists and would significantly increase the rate of mortality and/or morbidity in Canada as a result of an inability to provide timely services to Canadian citizens.

Net cost under (a) should be calculated by considering both the fiscal contributions the disabled prospective immigrants and her family are expected to make-i.e., through the paying of taxes — and the fiscal costs taxpayers will bear to provide services to the disabled prospective immigrant. The specification that net costs may be considered in the aggregate is intended to cover the possibility that, while the admission of one prospective immigrant with an expensive health condition may not lead to net costs sufficient to impair Canada's ability to realize one or more of its morally important purposes, a policy of admitting such prospective immigrants may do so. Condition (b) is necessary to capture the ways in which the admission of prospective immigrants with disabilities can impact Canada's ability to promote citizens' health other than through the imposition of financial costs, for example, by lengthening the wait-list for scarce goods such as organs for transplantation.

On this interpretation of "excessive demand," $38(1)(c)$ would significantly advance Canada's realization of its morally important purposes. Careful judgment is of course required to apply this standard in practice. I would suggest that a demand on health or social services would satisfy it if, to meet the demand in question, Canada had to reallocate tax dollars away from other government programs with the consequence of a significant decline in Canada's realization of its morally important purposes, e.g., an increase in the national or provincial rates of mortality and/or morbidity or a decrease in the number of low-income Canadians completing postsecondary education.

Canada's SCHR can therefore satisfy 1 if "excessive demand" is interpreted in the above-mentioned way. What about condition 2, the requirement that there is no less discriminatory means by which the discriminatory agent may significantly advance the realization of its purpose that would not result in undue burdens on it? Would this revised version of $38(1)$ (c) satisfy it?

Not necessarily. First, Canada may have the option of simply reallocating public funds from programs serving purposes that are not morally important or raising taxes. ${ }^{65}$ This option will of course not always be available. Canada may not fund any programs that can be characterized as morally unimportant, and 
governments are not able to raise unlimited amounts of revenue through taxation. Still, unless Canada is working with what we might call a "reasonably just budget"- that is, a budget under which it is taxing citizens appropriately and using those resources efficiently to fulfill its morally important purposes - then there is a less discriminatory option available to Canada that does not impose an undue burden on it.

Second, Canada may have other nondiscriminatory means of preventing the imposition of the above-mentioned costs. To see this, recall that, according to my account above, governments have a duty to ensure that people are not disadvantaged in the exercise of their freedom because of morally arbitrary features of their identity in a wide range of public and private spheres of interaction, e.g., the receipt of public benefits and services, employment, public accommodations, and housing. Consider next that this duty implies that governments must ensure that these spheres of interaction and the built environments in which they occur are designed in ways that are inclusive of persons with disabilities, i.e., to ensure that people with disabilities are not disadvantaged in the exercise of their freedom. Governments therefore have a duty to implement what Jonathan Wolff calls "status enhancement" policies for people with disabilities, "in which changes to social, material and cultural structure are made in order to modify the structural mediating factors between impairment and adverse consequences." ${ }^{66}$ For example, with respect to employment, governments must require that workplaces are accessible to people in wheelchairs. ${ }^{67}$

This duty is not unlimited. In certain spheres of interaction, particular disabilities may not be morally arbitrary and so governments need not ensure that people with the disabilities in question have the same opportunity as others to exercise their freedom. For example, people with cognitive disabilities severe enough to render them incompetent are disadvantaged in many spheres governed by private law since they may not make legally binding agreements without the mediation of a surrogate decision-maker. However, this discrimination is

Wolff, "Disability, Status Enhancement, Personal Enhancement and Resource Allocation," 51.

67

Indeed, proponents of the social model of disability would argue that it is possible to accommodate most if not all persons with disabilities though such changes in the social world. For them, the principal reason that many physical and mental characteristics lead to personal and social limitations for people-thus constituting disabilities-is because the social world-e.g., social practices and built environments- has been constructed in ways to exclude people with the characteristics in question. See Wasserman, Asch, Blustein, and Putnam, "Disability." 
arguably justifiable given the important purposes that existing systems of private law realize with the standard of competence that they employ. ${ }^{68}$

Consider finally that there may be cases in which the admission of a prospective immigrant with a disability is likely to lead to an "excessive demand" on Canada's health and social services only because Canada has not fulfilled its duty to ensure that people are not disadvantaged because of morally arbitrary features. For example, suppose for the sake of argument that a deaf prospective immigrant would satisfy the above-mentioned definition of an excessive demand, but that full compliance with its duty of inclusion would require Canada to structure its social world in a way that is fully inclusive of people whose hearing is limited or absent, e.g., by requiring all citizens to learn sign language. In this case, admission of the deaf prospective immigrant would only be likely to result in an "excessive demand" on Canada's health and social service programs-i.e., require certain forms of assistance-because Canada has not complied with its duty of inclusion. If Canada had done so, the prospective immigrant in question-as with deaf Canadians - would not require any form of assistance to live and work. In this type of case, while it would be legally permissible to refuse admission to the prospective immigrant in question under my revised version of $38(1)(\mathrm{c})$, doing so would not satisfy 2 . Canada would have available a nondiscriminatory means of preventing the admission of such prospective immigrants from resulting in an "excessive demand" on its health and social service programs - namely, designing its social world in an inclusive way, and this redesign would not require the imposition of an undue burden on Canada since Canada would have a duty of justice to carry it out anyway.

Now, this does not imply that no version of $38(1)$ (c) would satisfy 2 . There are likely to be prospective immigrants with certain types of disabilities whose admission would impact Canada's ability to realize its morally important purposes even if Canada fully discharged its duty to construct an inclusive social world, e.g., disabilities due to medical conditions such as HIV/AIDS that are expensive to treat, and significant cognitive disabilities requiring the provision of expensive social services. However, the possibility of the above-mentioned type of case means that we must revise the definition of "excessive demand" further such that it is:

(a) a demand on health services or social services for which the anticipated net costs, considered individually or in the aggregate, are great 
enough to significantly impact Canada's ability to realize one or more of its morally important purposes; or

(b) a demand on health services or social services that would add to existing waiting lists and would significantly increase the rate of mortality and/or morbidity in Canada as a result of an inability to provide timely services to Canadian citizens; and where

(c) the costs described in (a) and the significant increases in the rate of mortality and/or morbidity described in (b) would occur even if Canada implemented a reasonably just budget and fully discharged its duty to its existing disabled citizens to construct an inclusive social world.

My above account of permissible discrimination provides a framework for determining when certain disabilities are not morally arbitrary in the contexts of certain spheres of interaction and so are not covered by the duty of inclusion. Unfortunately, specifying which disabilities are covered by this duty and which are not requires complex normative and empirical judgments and so is beyond the scope of this paper. ${ }^{69}$

Finally, a revised version of $38(1)$ (c) must also satisfy 3 if it is to be permissible. Focusing on Canada, this means that the morally important purposes Canada realizes by means of my revised version of $38(1)(c)$ must be more valuable than the purposes of prospective immigrants that are frustrated by the discriminatory treatment.

Which set of purposes is more valuable? As a way of making headway on this difficult question, consider first that, in the context of a liberal theory of justice, we signal the value of different purposes through the application of certain deontic categories. Purposes for which it is morally imperative that they be carried out are ones that agents have a duty of justice to realize, or a claim of justice to be realized. Similarly, we assign rights to agents to protect their ability to set and pursue purposes that we deem to be particularly valuable. Purposes that are not the subject of these deontic categories, by contrast, are less pressing from the standpoint of justice, though they may still be valuable to the agents who have them. Thus, in a just Rawlsian society, citizens have basic rights and liberties that provide the institutional conditions necessary to realize their highest-order interest in developing and exercising their capacity for a conception of the good and that also protect their ability to set and pursue a wide variety of determinate

69 For further discussion of this question, see Wasserman, "Philosophical Issues in the Definition and Social Response to Disability"; Samaha, "What Good Is the Social Model of Disability?”; Wolff, “Disability, Status Enhancement, Personal Enhancement and Resource Allocation”; and Barclay, "Disability, Respect, and Justice." 
plans of life. ${ }^{70}$ They also have claims of justice to those goods and services necessary to fully develop and exercise their capacity for a conception of the good, including food, clothing, housing, and health care, and they have claims to a fair share of opportunities and income and wealth with which they may pursue a wide variety of ends. ${ }^{71}$ However, citizens in a just Rawlsian society do not have claims of justice to the realization of any particular determinate conception of the good life. Rawls puts the point this way:

Strong feelings and zealous aspirations for certain goals do not, as such, give people a claim upon social resources, or a claim to design public institutions so as to achieve these goals. Desires and wants, however intense, are not by themselves reasons in matters of justice. ${ }^{72}$

In the context of a liberal theory of justice, therefore, the more valuable purposes are those that agents have a right or duty to fulfill, or a claim of justice to have fulfilled; the less valuable purposes are those that are not the object of such deontic considerations. Thus, it is permissible for a Baptist school to discriminate against non-Baptist applicants for a teaching position on the grounds that the school has a right to provide a faith-based education to its students whereas teaching applicants do not have a claim of justice to work at a particular school. Similarly, it is permissible for public universities to employ diversity affirmative action policies since they have a duty to facilitate a rich educational environment, whereas college applicants do not have a claim to attend a particular university.

With these considerations in mind, we can return to the question at hand: which purposes are more valuable, the purposes Canada aims to realize through my revised version of $38(1)(\mathrm{c})$, or the purposes of prospective immigrants that would be frustrated by its implementation?

Consider first that the purposes Canada aims to realize through my revised version of $38(1)(c)$ are highly valuable. Canada has a right to implement policies to promote its citizens' health, meet their basic needs, ensure disadvantaged Canadians have fair opportunities, and facilitate economic growth. With the possible exception of the latter goal, Canada also has duties of justice to realize these purposes. As such they are highly valuable purposes.

The central purposes of many prospective immigrants that would be frustrated by $38(1)(c)$, by contrast, are the objects of neither a right nor a claim of justice. On the assumption that Canada has a moral right to exclude at least some prospective immigrants, prospective immigrants who may be justly excluded have

70 Rawls, Political Liberalism, 308.

71 Rawls, Political Liberalism, 7, 308, and Justice as Fairness, 171-73.

72 Rawls, "Social Unity and Primary Goods," 371-72. 
no right to secure permanent residency in Canada, and no claim of justice to this good. The goals these prospective immigrants seek to realize by securing permanent residency in Canada-e.g., advancing their career, bettering their economic prospects, or securing a wider range of opportunities for their children-are of course important ones. However, prospective immigrants who have no claim of justice to be admitted to Canada have no right to pursue these goals in Canada.

In the case of prospective immigrants who have no right or claim of justice to be admitted to Canada, therefore, Canada's purposes of promoting its citizens' health, meeting their basic needs, and securing fair opportunities for disadvantaged Canadians are more valuable than their purpose in securing permanent residency in Canada. Canada has a right and a duty of justice to realize these purposes, whereas the prospective immigrants in question do not have a right or claim of justice to permanent residency in Canada.

One might argue that this is the wrong way to compare the purposes of Canada on the one hand and prospective immigrants on the other. Instead, one might suggest, one should simply compare the interests of Canadian residents that would be promoted by $38(1)(\mathrm{c})$ with the interests of prospective immigrants that would be set back by this policy. To take a simplistic example, suppose that a prospective immigrant with end-stage renal disease wishes to be admitted to Canada because she is unlikely to secure a life-saving kidney transplant in her country of residence, and her chances are much better as a resident of Canada. Suppose that, given the limited supply of kidneys for transplantation in Canada, admitting this prospective immigrant will mean that a citizen of Canada with end-stage renal disease will be unable to secure a life-saving kidney. In this case, the interests of the prospective immigrant and the interests of the Canadian citizen are the same, so why not conclude that the purpose that Canada can realize by excluding this prospective immigrant is of equal value to the prospective immigrant's purpose of being admitted to Canada?

In response, consider first that this type of interest-to-interest comparison will not always imply that the purposes of prospective immigrants are of equal value to Canada's purposes. If we accept Rawls's claim that individuals' interests in securing their health, having their basic needs satisfied, and accessing fair opportunities are more important than individuals' interests in realizing their determinate conception of the good life, then there will likely be cases in which Canada's purposes will be more valuable than those of prospective immigrants seeking admission. This is so since some prospective immigrants will seek permanent residency in Canada simply because it advances their determinate conception of the good life, for example, because they can secure a more attractive job in Canada. 
More importantly, consider second that the interest-to-interest approach is too reductive. By simply examining the interests of individuals, it misses a normatively relevant piece of the picture - namely that Canada has a right and duty of justice to fulfill its morally important purposes, whereas the prospective immigrants in question have no right or claim of justice to secure admission in Canada. When Canada admits the prospective immigrant with end-stage renal disease, knowing the consequences for its own citizens of doing so, all else being equal, it fails to realize a morally important purpose that it has a right and duty of justice to realize: promoting the health of its citizens. By not admitting the prospective immigrant in question, by contrast, Canada violates no right nor fails to fulfill some claim of justice. An injustice occurs when Canada fails to promote its citizens' health but not when it excludes a prospective immigrant who has no claim to residency, and the interest-to-interest approach fails to recognize this.

The interest-to-interest approach would also prohibit a prima facie reasonable form of discrimination against prospective immigrants. Many countries require that certain occupations be filled by citizens or that citizens be given preference over foreign nationals in the hiring process. For example, if employers in the U.S. wish to permanently employ skilled foreign nationals, they must secure an approved labor certification from the Department of Labor that verifies that there are insufficient available, qualified, and willing U.S. workers for the position. ${ }^{73}$ On my account, such discrimination is permissible when it realizes some morally important purpose that either employers or governments have a right or duty to promote, e.g., protecting employment opportunities for citizens or promoting national security. On the interest-to-interest approach, by contrast, such discrimination is unjust since both citizens and foreign nationals will often have equally weighty interests in securing the job in question.

Canada's purposes are therefore more valuable than those of prospective immigrants who have no claim of justice to be admitted to Canada. What about prospective immigrants who do have such a claim? Since this purpose is also the object of a duty of justice, it is arguably as valuable as the purposes Canada aims to realize through $38(1)(\mathrm{c})$. Moreover, since the duty of justice in question obligates Canada to admit these prospective immigrants, my account of the wrongness of direct discrimination is largely beside the point. Canada has an obligation to admit these prospective immigrants and so they may not be subjected to $38(1)(\mathrm{c})$.

Which prospective immigrants have a claim of justice to be admitted to Canada? I have assumed in this paper that legitimate states have a limited moral right to exclude, citing Blake's and Miller's accounts of this right as the most promis- 
ing on offer. Blake and Miller also provide reasonable accounts of the limit to this right, and I shall appeal to them here. Both accounts start from the premises that people possess human rights and that high-income nations such as Canada have a shared duty of justice to protect and fulfill the human rights of people whose rights are inadequately protected and fulfilled in the countries in which they reside. Miller argues that legitimate states have a duty to admit their fair share of refugees, understood broadly as "people whose human rights cannot be protected except by moving across a border, whether the reason is state persecution, state incapacity, or prolonged natural disasters." ${ }^{.74} \mathrm{He}$ argues further that people whose human rights are currently under threat but who can be protected either through migration or through outside intervention should not be classified as refugees, but that legitimate states will often have a duty to admit them, if only for a limited period of time. ${ }^{75}$ Blake argues similarly that states may only exclude prospective immigrants if their human rights are adequately protected in the country in which they reside. ${ }^{76}$ As such, nations such as Canada possess a shared duty to admit prospective immigrants whose human rights are under threat in the country in which they reside, whether this is due to underdevelopment or state oppression. ${ }^{77}$

On the basis of these accounts, I suggest that Canada, at minimum, possesses a shared duty of justice to admit prospective immigrants whose human rights are not adequately protected in the countries in which they reside. Canada may not therefore subject these prospective immigrants to $38(1)$ (c). I refer to this obligation as a minimal obligation since it may turn out that Canada has stronger obligations to residents of low- and middle-income countries than either Blake or Miller recognizes. ${ }^{78}$ For example, perhaps Canada has a duty to admit certain prospective immigrants who cannot access necessary health care in their country of residency. Whether Canada does possess such stronger obligations depends on questions of global justice that I cannot resolve here. In recognition of this minimal obligation, I suggest that a further condition be added to $38(2)$ of the Immigration and Refugee Protection Act, the clause that specifies the prospective immigrants to whom $38(1)$ (c) does not apply. This further revision would ensure that $38(1)$ (c) would not be applied to prospective immigrants with disabilities to whom Canada owes a duty of justice to admit.

Miller, Strangers in Our Midst, 82-83, 92-93.

Miller, Strangers in Our Midst, 82.

Blake, "Immigration, Jurisdiction, and Exclusion," 125-26.

Blake, “Immigration, Jurisdiction, and Exclusion," 126-30.

Thanks to an anonymous reviewer for raising this possibility. 
We have thus arrived at a revised version of Canada's SCHR that would satisfy my account of permissible discrimination. The final policy is as follows:

38(1) A foreign national is inadmissible on health grounds if their health condition

(a) is likely to be a danger to public health;

(b) is likely to be a danger to public safety; or

(c) might reasonably be expected to cause excessive demand on health or social services.*

38(2) Paragraph (1)(c) does not apply in the case of a foreign national whose human rights are not adequately protected or fulfilled in their country of residence; or who is a spouse, common-law partner, caregiving parent, or dependent child of a foreign national whose human rights are not adequately protected or fulfilled in their country of residence. ${ }^{79}$

*An excessive demand is:

(a) a demand on health services or social services for which the anticipated net costs, considered individually or in the aggregate, are great enough to significantly impact Canada's ability to realize one or more of its morally important purposes; or

(b) a demand on health services or social services that would add to existing waiting lists and would significantly increase the rate of mortality and/or morbidity in Canada as a result of an inability to provide timely services to Canadian citizens; and where

(c) the costs described in (a) and the significant increases in the rate of mortality and/or morbidity described in (b) would occur even if Canada implemented a reasonably just budget and fully discharged its duty to its existing disabled citizens to construct an inclusive social world.

I would emphasize here that this revised version of $38(1)(\mathrm{c})$ outlines the conditions under which discrimination against prospective immigrants with disabilities is permissible. My position is not that such discrimination is required by justice, or even that it is on balance a good idea.

It is difficult to identify all of the implications of my analysis for existing policy. Although I have provided a definition of "excessive burden," it is more abstract than the current definition, outlining the factors that should be considered

79 Note that I have removed other conditions from $38(2)$. I have done so for the sake of simplicity, not because I think they are unjustifiable or ought to be removed. 
in the calculation of a cost threshold rather than presenting a specific amount. Immigration, Refugees and Citizenship Canada did not provide much justification for its decision to set the cost threshold at three times the average Canadian per capita cost and so I am not in a position to say whether my definition implies either a higher or lower threshold. Too much depends on data to which I do not have access. ${ }^{80}$

However, my analysis does have important implications for the specification of such a threshold. First, in the calculation of such a threshold, policymakers must consider the fiscal contributions that prospective immigrants with disabilities as well as members of their immediate families can be reasonably expected to make to the Canadian state. The relevant metric is net cost, not merely cost, which is the focus of the existing policy. Second, I see little reason for Immigration, Refugees and Citizenship Canada's decision to only consider costs to health and health-related social services, rather than social services more broadly. Canada realizes its morally important purposes through these latter services too, not merely through services that promote citizens' health. Third, policymakers must consider whether there are nondiscriminatory ways to prevent impacts on Canada's ability to realize its morally important purposes. Finally, my revision to $38(2)$ suggests that $38(1)$ (c) must not be applied to an additional class of prospective immigrants - namely, people whose human rights are inadequately protected or fulfilled in their country of residence; $38(2)$ currently only excludes people likely to be classified as refugees by the Geneva Convention.

The question of which prospective immigrants will satisfy this revised version of $38(1)$ (c) depends on complex empirical and normative judgments. However, it seems likely that very few if any will do so. My version of $38(1)(c)$ is more narrowly tailored than the existing policy, and the latter policy has already been restricted in its application from its previous instantiation quite substantially. Indeed, the requirement that Canada's SCHR be revised in accordance with my analysis implies that SCHRs must be structured and applied in similar ways to the health requirements that, as I note above, are prima facie reasonable-namely, those that require that prospective immigrants have no health conditions that pose a risk to public health or public safety. After all, on my account, to refuse admission to prospective immigrants with disabilities, receiving countries must demonstrate that admission poses a risk to the health of citizens or some other similarly weighty interest. In the case of my proposed revised version to Canmigration makes clear that very little is known about how changes to or the elimination of $38(1)$ (c) would impact Canada's health and social service programs. See Standing Committee on Citizenship and Immigration, Building an Inclusive Canada. 
ada's SCHR, $38(1)(\mathrm{c})$ is a recognition that the health conditions of prospective immigrants cannot only negatively impact citizens by posing a "danger" to public health or public safety, but also through resulting costs on health and social services programs.

\section{AN OBJECTION}

One might argue that even this narrowly tailored version of Canada's SCHR permits an objectionable form of disability discrimination. Adopting Deborah Hellman's account of the wrongness of discrimination-namely, that discrimination is wrong when and because it demeans people-one might argue that my proposed revision to Canada's SCHR is wrong because it demeans prospective immigrants with disabilities.

To better see the shape of this objection, consider first that, on Hellman's view, demeaning action "requires (1) an expression of the unequal humanity of the other and (2) that the speaker occupy a position of status such that this expression is one that can put the other down." ${ }^{81}$ Whether an act is demeaning is not dependent on whether its target feels demeaned, Hellman claims, but whether the act is demeaning in a modestly objective sense, the determination of which requires complex interpretative judgments regarding social practices. ${ }^{82}$ With respect to scHRs, Hellman might argue that these policies are wrongfully discriminatory since they violate 1 and 2. After all, the speaker in question is government, satisfying 2 , and, as a number of commentators have pointed out, SCHRs are often tied to a history of disrespectful treatment of disabled persons. ${ }^{83}$ Indeed, referencing Canada's SCHR, Lindauer adopts something like Hellman's view, writing that it "expresses the attitude that members with these disabilities are a burden on society, contributing less than they receive." He therefore concludes that such policies ought to be repealed. ${ }^{84}$ Thus, even if a narrowly tailored SCHR satisfies the above conditions of permissible discrimination, one might argue that it nonetheless demeans prospective immigrants with disabilities and so is wrong for that reason. ${ }^{85}$

Whether the narrowly tailored SCHR I propose above demeans prospective immigrants with disabilities depends on whether it expresses a demeaning or

81 Hellman, When Is Discrimination Wrong? 35-38.

82 Hellman, When Is Discrimination Wrong? 75-79.

83 See Hanes, "None Is Still Too Many."

84 Lindauer, "Immigration Policy and Identification Across Borders," 299.

85 For application of Hellman's view to the context of immigrant selection, see Lim, "Selecting Immigrants by Skill." 
disrespectful judgment about them. As I argue above, the most defensible justification for this policy is that it enables receiving countries to fulfill morally valuable purposes, for example, the promotion of citizens' health. Taking my revised version of $38(1)(c)$ as an example, permissible scHRs therefore express the following judgments about prospective immigrants with disabilities who might be refused admission under them:

1. The specific disabilities that prospective immigrants possess are likely to either result in net costs for Canada's health and social services or add to waiting lists in a way that would impact Canada's ability to realize its morally important purposes, including leading to an increase in morbidity and/or mortality rates among existing citizens.

2. Canada cannot avoid these costs-without suffering an undue burden-except through discriminatory treatment of the prospective immigrants in question.

3. Canada's fulfillment of its morally important purposes is more important than the fulfillment of prospective immigrants' purpose of securing permanent residency in Canada.

Do any of these claims express a demeaning or disrespectful judgment about prospective immigrants with disabilities?

Judgment 1 is largely an empirical claim, though it presupposes the normative claim that Canada's purposes of promoting citizens' health, meeting their basic needs, and securing fair equality of opportunity are morally important. This normative claim expresses no demeaning or disrespectful judgment, and I do not see how the empirical component of 1 can be construed to do so either. I would emphasize moreover that, on my account, discrimination against prospective immigrants with disabilities is only permissible when the empirical components of 1 are factual.

Consider Judgment 2 next. It includes the empirical claim that discriminatory treatment is the only policy Canada can employ to avoid the costs in question without suffering a burden of a certain size. Judgment 2 also includes the normative claim that a burden of this size counts as undue, i.e., is a burden it would be unreasonable to expect Canada to bear. As I note above, the underlying idea here is that there are limits to the steps governments must take to construct an inclusive society and so that, even if it were possible to avoid the costs in question through such nondiscriminatory measures, it would be unreasonable to expect governments to do so.

Hellman might argue that my claim that such limits exist is itself an example of a demeaning judgment. But, if this is so, it would seem to commit her to the 
claim that the current design of many spheres of private law, which do not allow people with severe cognitive disabilities to make legally binding agreements without the mediation of a surrogate decision maker, is an example of wrongful discrimination - an implication I take to be counterintuitive. In this case, 2 might presuppose a demeaning judgment about persons with disabilities, but this counterintuitive implication would give us reason to question whether the making of a demeaning judgment is a reliable indicator of wrongness.

In addition, even if I am wrong about this, it would only follow that Canada would be wrong to apply $38(1)$ (c) to prospective immigrants with disabilities whose admission would result in no costs if Canada restructured relevant private and public spheres of interaction in a fully inclusive way. As I note above, even in this case, there are still likely to be a variety of disabilities-e.g., those grounded in medical conditions that are expensive to treat— that would result in high costs for Canada's health and social service programs.

What about Judgment 3 ? Does it express the judgment that the lives of people with certain disabilities are worth less? I do not think so. As I note above, underlying 3 is the idea that Canada's purposes are more morally important because it involves the exercise of a right and the fulfillment of a duty of justice. Judgment 3 depends in no way, therefore, on the claim that the lives of persons with certain disabilities are worth less. On my account, the reason that it is permissible for the Canadian government to discriminate against prospective immigrants with certain disabilities is not because prospective immigrants without these disabilities are somehow more deserving of Canadian permanent residency. Instead, it is that Canada has a special responsibility to its citizens, and the realization of the associated purposes is more valuable than the granting of permanent residency to prospective immigrants. This is particularly evident in cases in which the reason for refusing admission to prospective immigrants with a certain disability is due to concerns that admitting them would increase waiting times for existing citizens with the same disability. In such cases, the difficult moral question Canada faces concerns the group of persons with disabilities it ought to prioritize: citizens or prospective immigrants. It is hard to see how my solution to this question expresses a demeaning judgment about people with disabilities given that this question simply does not concern the claims of nondisabled prospective immigrants.

\section{CONCLUSION}

Australia, Canada, and New Zealand all employ scHrs when determining which prospective immigrants to admit and grant permanent residency. Critics have 
charged that such policies wrongfully discriminate against prospective immigrants with disabilities. My aim in this paper has been to investigate this charge. Relying on a freedom-based account of the wrongness of discrimination, I have argued that there is a good deal of truth to critics' claims. However, I have argued that SCHRs are permissible when they are narrowly tailored to enable receiving countries to better realize their morally important purposes. I have focused my analysis on Canada's SCHR, suggesting how it may be revised to satisfy my account of permissible direct discrimination. However, since Australia's and New Zealand's schrs are structured in similar ways, my analysis has lessons for these policies as well.

In closing, I would note again that the mere fact that a narrowly tailored SCHR is permissible does not mean that countries ought-on balance-to employ these policies. It may be that the bureaucratic cost of employing such a policy simply outweighs the net costs the policy is intended to avoid, given the low number of prospective immigrants with disabilities who are likely to satisfy the conditions of a narrowly tailored SCHR. Receiving countries may also judge that it is reasonable to prioritize some morally important purposes over others. For example, Canada might judge that family reunification is important enough to justify not applying $38(1)$ (c) to family class prospective immigrants, even if doing so hinders Canada's ability to realize some of its other morally important purposes. Whether this is the case is a question I leave to policymakers to decide. My aim here has only been to work through the difficult moral question of whether such policies wrongfully discriminate against prospective immigrants with disabilities. This aspect of the debate has generated a good deal of heated discussion. I hope my analysis here helps shed some light on what is clearly a challenging question. ${ }^{86}$

University of North Carolina at Chapel Hill dmackay@email.unc.edu

Versions of this paper were presented at the Bioethics at the University of North Carolina at Chapel Hill (BUNC) Workshop; the 2017 New Research in Practical Philosophy Workshop at the University of Toronto; and the 2018 Meeting of the Philosophy, Politics, and Economics Society in New Orleans. For their helpful questions and comments, I thank audiences at these events. I am also grateful to two anonymous reviewers for their helpful feedback and suggestions. The final version of this paper is much stronger than the initial one, and a good deal of this improvement is due to their insightful and challenging comments. 


\section{REFERENCES}

Altman, Andrew. "Discrimination." Stanford Encyclopedia of Philosophy (Winter 2016). https://plato.stanford.edu/archives/win2016/entries/discrimination. Anastasiou, Dimitris, and James M. Kauffman. "The Social Model of Disability: Dichotomy between Impairment and Disability." Journal of Medicine and Philosophy 38, no. 4 (August 2013): 441-59.

Azpiri, Jon. "Case of Deaf Teenager Denied Immigration to Canada Discussed in House of Commons." Global News, May 27, 2015. http://globalnews. $\mathrm{ca} /$ news/2019602/case-of-deaf-teenager-denied-immigration-to-canadadiscussed-in-house-of-commons.

Barclay, Linda. "Disability, Respect, and Justice." Journal of Applied Philosophy 27, no. 2 (May 2010): 154-71.

Barnes, Elizabeth. The Minority Body. New York: Oxford University Press, 2016.

Beaudry, Jonas-Sébastian. “Beyond (Models of) Disability?” Journal of Medicine and Philosophy 41, no. 2 (April 2016): 210-28.

Bickenbach, Jerome. "Disability, 'Being Unhealthy,' and Rights to Health.” Journal of Law, Medicine and Ethics 41, no. 4 (Winter 2013): 821-28.

Blake, Michael. "Discretionary Immigration." Philosophical Topics 30, no. 2 (Fall 2002): 273-89.

- "Exclusion, Discretion, and Justice." In The Ethics and Politics of Immigration: Core Issues and Emerging Trends, edited by Alex Sager, 29-43. New York: Rowman and Littlefield, 2016.

- "Immigration and Political Equality." San Diego Law Review 45, no. 4 (November-December 2008): 963-79.

- "Immigration, Jurisdiction, and Exclusion." Philosophy and Public Affairs 41, no. 2 (Spring 2013): 103-30.

Canadian Broadcasting Corporation. "Deported, Disabled uk Citizen Arrives in Britain,” СВC News, January 20, 2009. http://www.cbc.ca/news/canada/ manitoba/deported-disabled-u-k-citizen-arrives-in-britain-1.845793.

Carens, Joseph. The Ethics of Immigration. New York: Oxford University Press, 2013.

Cole, Phillip, and Christopher Heath Wellman. Debating the Ethics of Immigration: Is There a Right to Exclude? New York: Oxford University Press, 2011.

Government of Canada. "Facts and Figures 2015: Immigration OverviewPermanent Residents-Annual IRcC Updates." http://open.canada.ca/data/ en/dataset/2fbb56bd-eae7-4582-af7d-a197d185fc93? ga $=2.262048846 .25662$ 7577.1511288946-2085398786.1511193746.

Hanes, Roy. "None Is Still Too Many: An Historical Exploration of Canadian 
Immigration Legislation as It Pertains to People with Disabilities.” Developmental Disabilities Bulletin 37, nos. 1 and 2 (2009): 91-126.

Harris, Kathleen. “'An Issue that Pulls at the Heartstrings': MPs Review Rules that Reject Immigrants on Medical Grounds.” СвС News, October 24, 2017. http: // www.cbc.ca/news/politics/immigration-rules-medical-inadmissibility $-1.4367826$.

Hellman, Deborah. When Is Discrimination Wrong? Cambridge, MA: Harvard University Press, 2008.

Immigration New Zealand. Operational Manual, A4.10. https://www.immigration.govt.nz/opsmanual.

Immigration, Refugees and Citizenship Canada. "Medical Requirements." September 2014. http://www.cic.gc.ca/english/resources/tools/medic/index. asp.

. "Temporary Public Policy Regarding Excessive Demand on Health and Social Services.” 2018. https://www.canada.ca/en/immigration-refugeescitizenship/corporate/mandate/policies-operational-instructionsagreements/excessive-demand-june-2018.html.

Khaitan, Tarunabh. A Theory of Discrimination Law. New York: Oxford University Press, 2015.

Lim, Desiree. "Selecting Immigrants by Skill: A Case of Wrongful Discrimination?" Social Theory and Practice 43, no. 2 (April 2017): 369-96.

Lindauer, Matthew. "Immigration Policy and Identification Across Borders." Journal of Ethics and Social Philosophy 12, no. 3 (December 2017): 280-303.

Lippert-Rasmussen, Kasper. Born Free and Equal? A Philosophical Inquiry into the Nature of Discrimination. New York: Oxford University Press, 2013.

MacKay, Douglas. “Are Skill-Selective Immigration Policies Just?” Social Theory and Practice 42, no. 1 (January 2016): 123-54.

- "Calculating QALYs: Liberalism and the Value of Health States." Economics and Philosophy 33, no. 2 (July 2017): 259-85.

. "Coercion and Distributive Justice: A Defense." Journal of Social Philosophy 47, no. 2 (Summer 2016): 211-30.

McCulloch, Sandra. "American University Professor in B.C. Denied Permanent Residence in Canada Due to Autistic Son.” National Post, March 29, 2012. https://nationalpost.com/news/canada/american-university-professor -in-b-c-denied-permanent-residence-in-canada-due-to-autistic-son.

McQuigge, Michelle. “Ontario Family Denied Residency over Son's Down Syndrome." Toronto Star, March 20, 2016. https://www.thestar.com/news/ canada/2016/03/20/ontario-family-denied-residency-over-sons-downsyndrome.html. 
Miller, David. Strangers in Our Midst: The Political Philosophy of Immigration. Cambridge, MA: Harvard University Press, 2016.

Moreau, Sophia. "What Is Discrimination?" Philosophy and Public Affairs 38, no. 2 (Spring 2010): 143-79.

Rawls, John. Justice as Fairness: A Restatement, edited by Erin Kelly. Cambridge, MA: Harvard University Press, 2003.

. "Kantian Constructivism in Moral Theory." In John Rawls: Collected Papers, edited by Samuel Freeman, 303-58. Cambridge, MA: Harvard University Press, 1999.

- Political Liberalism. New York: Columbia University Press, 2005.

. "Social Unity and Primary Goods." In John Rawls: Collected Papers, edited by Samuel Freeman, 359-87. Cambridge, MA: Harvard University Press, 1999.

- A Theory of Justice. Cambridge, MA: Harvard University Press, 1999.

Samaha, Adam M. "What Good Is the Social Model of Disability?" University of Chicago Law Review 74, no. 4 (Fall 2007): 1251-308.

Scheffler, Samuel. "What Is Egalitarianism?" Philosophy and Public Affairs 31, no. 1 (Winter 2003): 5-39.

Shakespeare, Tom. Disability Rights and Wrongs Revisited. New York: Routledge, 2013.

Shiffrin, Seana Valentine. "Incentives, Motives, and Talents." Philosophy and Public Affairs 38, no. 2 (Spring 2010): 111-42.

Standing Committee on Citizenship and Immigration. Building an Inclusive Canada: Bringing the Immigration and Refugee Protection Act in Step with Modern Values. 42nd Parliament, 1st Session, December 2017. https:// www.ourcommons.ca/DocumentViewer/en/42-1/CIMM/report-15.

United Nations. "Standard Rules on the Equalization of Opportunities for People with Disabilities." 1993.

Waldeck, Elizabeth, and Robert Guthrie. "Disability Discrimination and Immigration in Australia." International Journal of Discrimination and the Law 8, no. 4 (March 2007): 219-36.

Wasserman, David. "Philosophical Issues in the Definition and Social Response to Disability." In Handbook of Disability Studies, edited by Gary L. Albrecht, Katherine D. Seelman, and Michael Bury, 219-51. Thousand Oaks, CA: Sage Publications, 2001.

Wasserman, David, Adrienne Asch, Jeffrey Blustein, and Daniel Putnam. "Disability: Definitions, Models, Experience." Stanford Encyclopedia of Philosophy (Summer 2016). https://plato.stanford.edu/archives/sum2016/entries/ disability. 
White, Ryan. "Physician's Family Fractured after Child with Cerebral Palsy Denied Entry to Canada." CTV News Calgary, May 5, 2016. http://calgary. ctvnews.ca/physician-s-family-fractured-after-child-with-cerebral-palsydenied-entry-to-canada-1.2889944.

Wikler, Daniel. "Paternalism and the Mildly Retarded." Philosophy and Public Affairs 8, no. 4 (Summer 1979): 377-92.

Wilton, Robert, Stine Hansen, and Edward Hall. "Disabled People, Medical Inadmissibility, and the Differential Politics of Immigration." Canadian Geographer 61, no. 3 (Fall 2017): 389-400.

Wolff, Jonathan. "Cognitive Disability in a Society of Equals." Metaphilosophy 40, nos. 3-4 (July 2009): 402-15.

. "Disability, Status Enhancement, Personal Enhancement and Resource Allocation." Economics and Philosophy 25, no. 1 (March 2009): 49-68.

World Health Organization. World Report on Disability. Geneva: World Health Organization, 2011.

Yu, Nilan G. "Ableism and Economic Rationalism in Australian Immigration." International Journal of Social Welfare 23, no. 3 (July 2014): 254-61.

Zaikowski, Carolyn. "Canada Is a Progressive Immigration Policy DreamUnless You Have a Disability.” Washington Post, February 3, 2017. https:// www.washingtonpost.com/posteverything/wp/2017/o2/o3/canada-is-a -progressive-immigration-policy-dream-unless-you-have-a-disability/. 